\title{
Construction and Verification of Effectiveness of English Listening Teaching Model Based on Interactive Model Theory*
}

\author{
Min Wang \\ School of Foreign Languages, Jining Medical University, Rizhao, Shandong Province, China \\ Fanghui $\mathrm{Hu}$ \\ School of Foreign Languages, Jining Medical University, Rizhao, Shandong Province, China
}

\begin{abstract}
Listening teaching is an important part in English teaching. On the basis of analysis of disadvantages of traditional English listening teaching in China, teaching model of English listening based on interactive model theory is constructed. The newly constructed teaching model consists of six teaching modules, including phonetic teaching, vocabulary teaching, grammar teaching, discourse teaching, background information teaching and strategy teaching. In order to test the effectiveness of the new model, two natural classes are chosen from some university. The control group adopted traditional listening teaching model while the experimental group new model. Independent samples test of SPSS was adopted to analyze their listening scores in pretest and posttest. The results show that the new English listening teaching model is significantly effective in improving students' listening proficiency $(P<0.05)$. New model of English listening teaching is worth popularization.
\end{abstract}

Index Terms — listening comprehension, interactive model theory, teaching model, English listening

\section{INTRODUCTION}

A large amount of comprehensible input contributes to language acquisition, and language input by way of listening plays a crucial role in acquiring a language (Hedge, 2002). Listeners also recognize listening as the most difficult course in foreign language learning (Granham, 2002). Meanwhile, the listening teaching is also one of the most important courses in language teaching (Elisha-Primo et al 2010). Listening teaching has been an important link in ESL (English as a Second Language) or EFL (English as a Foreign Language) Learning, which is also recognized in the field of foreign language teaching.

In China, although there are some researches about listening teaching methods, skills, and strategies (He \& Huang, 2011; Shi, 2012), there is not a systematic teaching model of English listening. At present, college students are particularly weak in English listening in China. Cultivation of Chinese EFL learners' listening ability is consequently a greatly difficult as well as significant task in English teaching (Jian, 2015).

Therefore, based on analysis on disadvantages of traditional teaching model of English listening, the paper tries to construct a new teaching model of English listening based on interactive model theory, which will be significant in improving English listening teaching in China.

\section{Disadvantages of Traditional Teaching Model of English Listening}

The traditional teaching model of English listening, which is based on behaviorist theory, has some disadvantages as follows.

\section{A. Tedious Teaching Process}

Under the traditional teaching model of English listening, the whole teaching process is basically divided into three parts: explanation of vocabulary before listening, listening to the material, and checking the answer. The process is rather tedious and it is difficult to effectively attract students' attention. However, only those input which has been noticed can be changed into intake and used to process information effectively $(\mathrm{Xu}, 2016)$. Besides, teachers play the role of turning on and off the player, playing the English audio material again and again. Moreover, one or twice English listening class in a week cannot provide sufficient listening input. All those result in lower levels of English listening after one semester. In the end, students will have negative feelings, losing interest in English listening. Negative feelings, tedious learning content and dull teaching model are the main reasons for learning interest (Wang,

\footnotetext{
* This paper is supported by National Training Program of Innovation and Entrepreneurship for Undergraduates (201610443030) and Undergraduate Training Program for Innovation of Jining Medical University (cx2016030).
} 
2012).

\section{B. Weak Teaching Practice}

Some so-called new teaching model of English listening, which aims to improve teaching effectiveness, are only limited to theory discussion. They are not applied to listening teaching practice. Some hypotheses cannot be verified because of the limitedness of software and hardware facilities.

All and all, traditional teaching model of English listening in China cannot effectively arouse students' interest in learning English listening and their listening proficiency cannot be improved due to the dull and tedious teaching model. Therefore, it is imperative that we explore a new English listening teaching model to improve the effectiveness of English listening class within limited time.

\section{Construction of New Teaching Model of English Listening Based on Interactive Model Theory}

\section{A. Interactive Model Theory of Listening Comprehension}

Interactive model theory was proposed by Rumelhart (1975) when he researched reading comprehension, while it is also applied to the process of listening comprehension (Flowerdew\& Miller, 2005). Interactive Model Theory of Listening Comprehension is combination between bottom-up model and top-down model.

Bottom-up model was proposed by Shannon and Weaver (1949). According to this model of listening comprehension, listeners comprehend the auditory information from the single phoneme. That is to say, the process of listening comprehension begins from the lower level of segments to the higher level of syllables, words, phrases, clauses, sentences and finally the meaningful discourse. Hence, enriched knowledge about language is necessary for listeners to comprehend listening material based on bottom-up theory.

On the contrary, top-down model is different from bottom-up model in that the former model doesn't depend on processing a single segment or a single word, while it focuses on the effect that listeners' previous knowledge have on processing information. The way of processing information with help of context and listeners' previous knowledge about the world is called top-down processing (Anderson, 2000).

According to the interactive model theory, second language learners adopt both bottom-up model and top-down processing in listening comprehension. Namely, on one hand, listeners inductively form sentences based on sounds and words, understanding sentences with the language grammar. On the other hand, they also use their previously mastered knowledge to help them understand sound information (Wang, 2013).

To sum up, listening comprehension is the combination between bottom-up processing of information and top-down process of information. With these two ways, listeners can succeed in decoding the new vocal symbols.

\section{B. Construction of New Teaching Model of English Listening}

The new teaching model of English listening is different from the traditional one in that the new model can reach the final goal of improving students' listening comprehension by way of cultivating their ability of processing auditory information interactively. The new model is shown in Fig. 1.

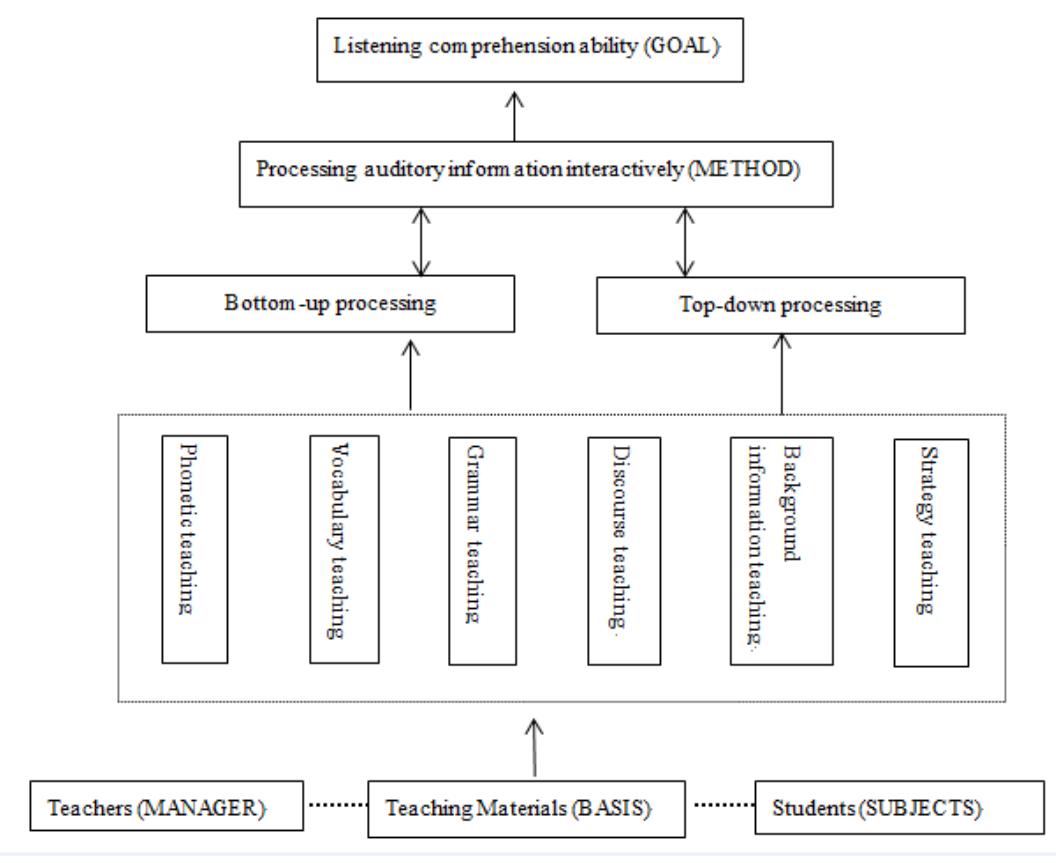

Figure 1. New teaching model of English listening based on interactive model theory 
Under the new model, teaching goal, content, key points and difficult points, method are all different from the traditional one. Simply speaking, through improving students' ability of interactive processing information, the goal of improving their listening proficiency will be reached. Teaching key points and difficult points will depend on teaching content.

Under the new teaching model of English listening, Teachers are the leader or manager of guiding students who are the learning subjects to be aware of interactively processing information. Based on teaching materials, classroom teaching consists of six modules_phonetic teaching, vocabulary teaching, grammar teaching, discourse teaching, background information teaching and strategy teaching. The former three modules are mainly used to cultivate students' ability of bottom-up processing of auditory information, while the latter three modules are mainly used to train students' ability of top-down processing of auditory information. With the improvement of students' ability of interactively processing information, their English listening proficiency will also be raised. The six teaching modules will be introduced in detail as follows.

1. Phonetic teaching

Phonetic teaching aims to guide students to focus on distinction between similar sounds, segmentation of fluent speech, assimilation, linking, incomplete plosion and contraction, stress, intonation, and rhythm and so on. The phonetic factors causing the comprehension difficulty should be intensively analyzed when the students meet with the phonetic obstacles, because the listening level can be improved when phonetic obstacles are overcome in learning a second or foreign language (Hu, 2017). Explanation of English phonetic knowledge and training are necessary, because phonetic perception is the first step to listening comprehension.

2. Vocabulary teaching

In listening comprehension, vocabulary is greatly important. Insufficient vocabulary will directly influence listeners' understanding of the material. Moreover, whether a person masters a word accurately will also have an effect on listening comprehension. Under the new teaching model of English listening, vocabulary teaching is not limited to pre-listening vocabulary teaching. Vocabulary guessing teaching during listening and depth and width of vocabulary will be emphasized after listening. In the process of teaching English vocabulary, in order to enlarge students' listening vocabulary and improve the speed and accuracy of matching the phonetic form and meaning of a word, teachers can design some tasks to raise students' awareness of learning the new vocabulary. For example, students are encouraged to repeat the new words. Teachers can also stop the player when a new word occurs in a text and let students repeat the pronunciation of the word so that the students can have the chance to memorize the phonetic form of the new word. Furthermore, teachers can guide students to guess the word's meaning through making use of the context or background information. Besides, some methods of memorizing words should be introduced to help students master more words. When listening vocabulary is enlarged, listening comprehension ability is also naturally improved.

3. Grammar teaching

Whether a student well masters the grammar or not can directly affect the accuracy of listening comprehension. Grammar teaching mainly includes analysis of the long and difficult sentences. Teachers can choose some typically long and difficult sentences and then help students analyze their grammatical structure, which is beneficial for students to recognize the differences between English and Chinese. In addition, in order to relieve students' anxiety, some playing software can be used to slow down the speed of the audio material or appropriately stop the audio material according to the meaning groups.

4. Discourse teaching

Discourse teaching aims to teaching cohesive devices of discourses, characteristics of discourses of different styles and so on. Introduction to common cohesive devices can help students understand the discourse structure and then understand the main idea of the whole text. Explanation of the characteristics of discourses of different styles can also help students construct the schema of relevant discourses.

5. Background information teaching

Background information teaching refers to teaching background information about the theme of the listening materials. For example, teaching cultural background in listening could provide students a faster way to understand the listening material (Wei, 2016). Through introduction to the cultural background information in listening teaching, students can immediately grasp the effective information and their comprehension ability will be finally improved (Qu \& Ren, 2014).

6. Strategy teaching

Listening strategy teaching should be added into listening teaching, which will bring about a better effect than traditional teaching model of English listening (He, 2016). It has been evidenced that strategy training can improve students' listening achievements (Wang, 2016). Listening strategy teaching includes metacognitive strategy teaching, cognitive strategy teaching and effect/social strategy teaching. Teachers can make a strategy format before the class and guide students to use it in class listening, which will help student form a good habit of using listening strategies when they listen.

Generally speaking, phonetic teaching, pre-listening vocabulary teaching, grammar teaching, and teaching of cohesive devices are all beneficial to bottom-up processing meaning of words, sentences and discourses. And guessing meaning of words during listening, teaching background information and listening strategies are helpful for students to 
train their ability of top-down processing of sound symbols.

All in all, under the new teaching model of English listening, students will not be the negative receivers for auditory symbols. Instead, they are active in making use of English phonetics, vocabulary, grammar and discourse, triggering background information in their minds, and matching and validating meaning and sounds. Teachers will not play the role of turning on and off the player, while they are the guider, leader and helper in teaching listening comprehension.

\section{VerificAtion of NeW TeAChing Model of ENGLish Listening}

\section{A. Subjects and Method}

\section{Subjects}

Two natural classes of freshmen of English majors in some college in China are randomly chosen as the subjects of the experiment. The two classes are taught by the same teacher. One is randomly recognized as the control group, the other one is experimental group. The control group adopts traditional teaching model of English listening, while the experimental group adopts the new teaching model of English listening.

\section{Method}

Testing material: pretest adopts the listening materials of CET4 (College English Test Band 4) in June, 2012, while posttest adopts that in December, 2012. The full score is 25 . The validity and reliability can be both higher because CET4 is an authoritative examination around China. All of the students participating in the experiment had never taken the CET4 in 2012. In order to guarantee the authenticity of the test results, students will be told to listen carefully. Cheating is not allowed.

Procedure: firstly, the pretest was taken simultaneously by the experimental group and control group in March, 2016. Then, the new teaching model of English listening was adopted in the experimental group. The teaching period was from March to May, which was all together twelve teaching weeks. Finally, the posttest was taken in late May. In the end, the achievements of every student in experimental group and control group were calculated and sorted out. SPSS 22.0 was used to analyze the relevant data.

\section{B. Results}

The pretest achievements can be seen in Table 1 .

TABLE I.

INDEPENDENT-SAMPLES TEST IN PRETEST

\begin{tabular}{l|l|l|l|l|l|l}
\hline & Control Group $(n=27)$ & Experimental Group $(n=28)$ & MD & \multirow{2}{*}{$t(53)$} \\
\cline { 2 - 5 } & $\mathrm{M}$ & $\mathrm{SD}$ & $\mathrm{M}$ & $\mathrm{SD}$ & & \\
\hline Achievements & 13.96 & 4.31 & 13.60 & 4.54 & 0.36 & 0.30 \\
\hline
\end{tabular}

Through the independent-samples test, the results show that the average score of the control group is 13.96 , and standard deviation (SD) is 4.31. The average score of the experimental group is 13.60, and the standard derivation is 4.54. The mean difference (MD) is 0.36 . On one hand, it proves that students' English listening proficiency is rather low, because of the average score of the subject is only below 14 (out of 25). On the other hand, the listening achievements between the control group and experimental group is not greatly different $(t(53)=0.30, P>0.05)$. That is to say, the listening level of the control group is generally equal to that of the experimental group.

The posttest achievements can be seen in Table 2 .

TABLE II.

INDEPENDENT-SAMPLES TEST IN POSTTEST

\begin{tabular}{|c|c|c|c|c|c|c|}
\hline & \multicolumn{2}{|c|}{ Control Group $(n=27)$} & \multicolumn{2}{|c|}{ Experimental Group $(n=28)$} & \multirow[t]{2}{*}{ MD } & \multirow[t]{2}{*}{$t(53)$} \\
\hline & $\mathrm{M}$ & SD & $\mathrm{M}$ & SD & & \\
\hline Achievements & 16.96 & 3.95 & 20.46 & 4.93 & -3.50 & $-2.90 *$ \\
\hline
\end{tabular}

The results in independent-samples test in posttest show that the average score of the control group is 16.96, and standard deviation (SD) is 3.95. The average score of the experimental group is 20.46 , and the standard derivation is 4.93. The mean difference (MD) is -3.50 .

To begin with, both the groups improved their listening proficiency. However, the experimental group improved higher than the control group. More importantly, Table II shows that students adopting new teaching model of English listening were significantly different from those adopting traditional teaching model of English teaching on CET4 listening $(t(53)=-2.90, P<0.05)$. Inspections of the two group means indicate that the average CET4 score of students using new teaching model of English listening(20.46) is significantly higher than the score of students using traditional teaching model (16.96).

\section{Discussions And SugGestions}

\section{A. Discussions}


Based on the results above, we can see that there is no great difference between the control group and the experimental group in the pretest. They are two parallel classes. In the posttest, both the groups improved their English listening proficiency. Moreover, there is great difference between the two groups in the posttest. The experimental group which adopted the new teaching model of English listening gained higher score than the control group which adopted the traditional teaching model of English listening. And the difference between those two groups is statistically significant. That is to say, it is the new teaching model of English listening that leads to the higher score of the experimental group. And the new teaching model of English listening based on the interactive model theory is effective.

The results also verify that listening comprehension, just like reading comprehension, is also the combination of bottom-up process and top-down processing. The listeners construct hypothesis as they are listening, and meanwhile they match the hypothesis with the auditory information they latter listen. Then, some hypotheses are confirmed, while others are not and then maybe corrected according to new information.

Although the difference between the means of the control group and the experimental group is 3.5, it is statically significant. After all, the experimental groups only adopted the new teaching model for twelve weeks. If the time is longer, the different between the means of these two groups must be greater.

There are some suggestions for English listening teaching in English as second or foreign language countries, based on the new constructed teaching model and its effectiveness in improving EFL learners' listening proficiency.

\section{B. Suggestions}

1. Suggestions for teachers and students

On one hand, teachers should change their role in English listening teaching. They are the manager of the whole class, guiding students to complete some tasks in or after the class. Hence, firstly, teachers should make a good preparation before the class. For example, some words which have different meaning just because they are stressed differently could be prepared to let students listen so that they can be trained to be sensitive to the stress of a word and its meaning. To a certain extent, teachers should not be limited to the textbook. Additional listening materials should be chosen with care to be used in the listening class. Secondly, teachers should assign some relevant tasks to students so that they can practice what they have learnt in the class. Only in this way can they enhance their awareness of applying knowledge they learned to listening comprehension in the class. Thirdly, teachers should explain some knowledge about the process of listening comprehension. That listening comprehension is the combination of bottom-up processing and top-down processing should be introduced to the students. In this way, they can have a good understanding of the process of listening comprehension, and they will come to know how to improve their listening ability.

On the other hand, students should first realize that listening comprehension of combination of bottom-up processing and top-down processing and raise their consciousness of interactive processing information. Besides, they should also realize that they can be active in listening. That is to say, students should make full use of their language knowledge, background information and strategies to actively imagine, predict and verify information they listen. The process of listening comprehension is not a negative process of receiving sound symbols.

2. Suggestions for improving interactive processing of information

It has been proved that listening comprehension depend greatly interactive processing (bottom-up processing and top-down processing). Knowledge about English phonetics, vocabulary, grammar, discourse, background information and strategies in listening comprehension are all helpful for improving listening proficiency, because they are useful in the interactive processing in listening comprehension. In this part, we will introduce some concrete methods to improve students' ability of bottom-up processing and top-down processing.

1) Improving bottom-up processing ability

There are several important tips for improving students' bottom-up processing ability. The ability of distinction between similar segments and segmentation of fluent speech, the quick matching between word sound and its meaning, the syntactic characteristic of words and sentences are all basis for quicken bottom-up processing in listening comprehension. Hence, students must master the knowledge of English pronunciation and intonation, enlarge their vocabulary, especially listening vocabulary, and acquire English grammar. In addition, some knowledge about cohesive devices can also be helpful for students to understand the logic of the whole discourse. Besides, accurate understanding of a word and a sentence is the good beginning of using the strategy of making inferences and predication in listening.

2) Improving top-down processing ability

In order to improve top-down processing ability, students should get knowledge of discourse. For example, the different styles of discourse. With the knowledge of different style of discourses, students could quickly grasp the key information they should focus. For example, when students listen to a novel, they should pay attention to the plot and details of the story. If they listen to news, they should focus on the former part or even the first sentence, because the main idea of the news is generally at the beginning part. In addition, the background information can provide students with a good understanding of the main idea of the whole text, and even it can help listeners make inferences of meaning of some words, phrases and sentences.

To sum up, bottom-up processing and top-down processing are combined in listening comprehension. They complement one another.

\section{CONCLUSION}


Listening teaching has not a fixed model. Teachers and researchers tries to construct a relevantly effective teaching model of English listening based on different theories. In this study, a new teaching model of English listening is based on the interactive model theory. This new model is more systematic, flexible and concrete than the traditional teaching model based on behaviorism. This new model can effectively cultivate students' language ability, enlarge their background information and improve their ability of using listening strategies in listening comprehension. Based on both bottom-up processing and top-down processing, students can decode the sound symbols interactively and actively. In addition, it can enliven the learning atmosphere in classroom and enhance students' confidence in improving English listening.

The results of the experiment also prove that the new teaching model of English listening can effectively improve students' listening proficiency. It could be applied in English listening teaching in colleges and universities in China. And the new teaching model of English listening also set an example for ESL or EFL listening in other countries.

The limits of the study lie in that it didn't investigate differences between low-proficiency and high-proficiency students. Maybe they have difference preference for choosing bottom-up processing or top-down processing. This could be the next topic for the latter researchers.

\section{REFERENCES}

[1] Anderson, J. R. (2000). Cognitive Psychology and Its Implications (5th ed.). New York: Worth Publishing.

[2] Elisha-Primo, I., Sandler, S., Goldfrad, K. et al. (2010). Listening to students' voices: A curriculum renewal project for an EFL graduate academic program. System 38, 457-466.

[3] Flowerdew, J. \& Miller, L. (2004). Second language listening: theory and practice. New York: Cambridge University Press.

[4] Gramham, S. (2002). Experiences of learning French: A snapshot at Years 11, 12 and 13. Language Learning Journal 25, $15-20$.

[5] He, Zaiyu. (2016). Application of listening strategy training in listening teaching English majors. Education Modernization 29, 336-337.

[6] Hedge, T. (2002). Teaching and learning in the language classroom. Shanghai: SFLEP.

[7] He, Shuangfeng. \& Huang Shuchun. (2011). Exploration of Multi-dimensional Teaching Model for English Majors'Listening under Network. Journal of Hunan City University 32.6, 89-91.

[8] Hu, Fanghui. (2017). A study on Chinese EFL learners' phonetic obstacles to listening comprehension. Journal of Language Teaching and Research 8.2, 404-410.

[9] Jian, Lihua. (2015). Teaching model of English listening based on scheme theory. Journal of Hunan University of Science and Engineering 36.9, 127-128.

[10] Qu, Chaoyi. \& Ren, Peihong. (2014). The research of web-based listening model for English majors. Journal of Jixi University 14.1, 82-84.

[11] Rumelhart, D.E. (1975). Notes on a schema for stories. In D.G. Bobrow \& A. Collins (Eds.). Representation and Understanding: Studies in Cognitive Science. New York: Academic Press.

[12] Shannon, C. E. \& Weaver, W. (1949). A Mathematical Model of Communication. Urbana, IL: University of Illinois Press.

[13] Shi, Qian. (2012). Construction of new teaching model of listening for English majors-based on constructivism. Journal of Zhengzhou Institute of Aeronautical Industry Management ( Social Science Edition) 31.5, 89-91.

[14] Wang, Lei. (2012). A survey and analysis of students' English learning interests in Jining Medical University. Journal of Jining Medical University 35.2, 149-151.

[15] Wang, Xiaojing. (2016). A study on teaching model of college English listening bases on cognitive strategy theory. Foreign Language Education 37.2, 65-68.

[16] Wang, Yan. (2013). Teaching and researching English listening. Beijing: Foreign Language Teaching Research Press.

[17] Wei, Yuemei. (2016). A study on leading culture in college English listening teaching. Journal of Lvliang Education Institute 33.4, 59-61.

[18] Xu, Lu. (2016). Exploration of effectiveness of noticing strategy in college English listening teaching. Foreign Language World $176.5,89-96$.

Min Wang was born in Linyi, China in 1995. She is currently an undergraduate student of school of foreign language of Jining Medical University, Rizhao, China. Her research interests include English phonetics and second language acquisition.

Fanghui Hu was born in Jining, China in 1981. She received her Master Degree from Hunan University in 2007.

She is currently a lecturer in School of Foreign Languages, Jining Medical University, Rizhao, China. She has been teaching in Jining Medical University for eleven years; course taught include English listening, Introduction to Linguistics, English writing, and Stylistics. Her research interests include second language acquisition and language testing. 